\title{
PROTECTION OF THE NON-REGISTERED TRADEMARKS IN THE FRAMEWORK OF THE DECREE LAW NO: 556 IN TURKEY
}

\author{
Seniha DAL ${ }^{[*]}$
}

\begin{abstract}
Decree Law effective in the year 1995 in our country "Decree Law on the Protection of Trademarks No 556" has taken the registration system as a base in the protection of trademarks. For this reason, trademarks registered at the trademark registry established under the Turkish Patent Institute in Turkey, provide their owners the right of monopoly. However, it does not mean that a trademark that is not registered as to the clauses of the Decree Law No: 556 are not protected within the borders of our country. Even though the protection of trademarks depends on the registry basis as to the Decree Law No: 556; a trademark not registered in accordance to the procedure is also protected as to the mentioned legislation. In this study the regulations of the Decree Law No: 556 permitting the protection of a nonregistered trademark within the borders of Turkey related to the topic will be discussed.
\end{abstract}

Keywords: Non-registered trademark, The Decree Law No: 556 in Turkey

\section{SAYILI KHK KAPSAMINDA TESCİLSİZ MARKALARIN TÜRKIYYE'DE KORUNMASI}

Öz

Ülkemizde 1995 yılında yürürlüğü giren "556 sayılı Markaların Korunması Hakkında Kanun Hükmünde Kararname (KHK)" markaların korunmasında tescil sistemini esas almıştır. Bu nedenle Türkiye'de Türk Patent Enstitüsü nezdinde kurulan marka siciline tescil edilen markalar sahibine tekel hakkı verir. Ancak Türkiye'de bir markanın 556 sayılı KHK hükümlerine göre tescil edilmemiş olması o markanın ülkemiz sınırları içinde korunmayacağı anlamına gelmemektedir. Her ne kadar 556 sayılı KHK uyarınca markaların korunması tescil esasına dayanmakta ise de usulüne göre tescil edilmeyen bir marka da anılan mevzuat uyarınca korunabilmektedir. Bu çalışmada Türkiye sınırları içinde tescilsiz bir markanın korunmasına izin veren 556 sayılı KHK’nın konuya ilişkin düzenlemeleri ele alınacaktır.

Anahtar Kelimeler: Tescilsiz marka, Türkiye'de 556 sayılı kanun

${ }^{[*]}$ Yrd.Doç.Dr. Marmara University, Faculty of Business Administration, senihadal@marmara.edu.tr 


\section{Introduction}

Economic value, in the current century where the transformation from the industrial society to the information society is experienced, is expressed by intellectual capital rather than financial capital. In the knowledge economy formed during the globalization process, the production based on concrete entities was replaced by production based on information formed by abstract entities. In the global world system where trade borders are eliminated day after day and technology develops at an unbelievable pace, intellectual capital ownership has become an important means in the determination of the competitive power in the international field. It is fundamental to protect intellectual property rights, which carry great importance both in the domestic and in the international trade, in an equal and effective manner worldwide. In order to enable the effective and widespread protection of these rights, the establishment of the intellectual rights conscience in the wide section of the society must be conferred. Two things are important in the protection of intellectual rights. The first one of these is that the person spends a specific effort to create a work. The second one is that as the protection of the created work encourages the person in the subject of creation, she/he earns a financial income at the result of these activities. The person creating a work has both the material and moral rights on her/his work. The creative power of the human mind and will is the source of the works in both industrial and artistic fields. For this reason, it is very important for these works to be protected. Effective protection of the intellectual rights is one of the most important elements in the establishment of a healthy and strong industry. In order for the countries to realize a sustainable development, the protection of intellectual rights and the principle of respect to the intellectual rights must be established.

There are two fundamental systems; one based on registry and the one not based on registry, in the protection of the rights based on intellectual property in the world. According to its law tradition, intellectual property protection could be based on registry or based on non-registry in different countries. One of these systems is also chosen in obtaining the right on trademark which is also an intellectual property. In our country, according to the Decree on the Protection of the Trademarks No. 556, effective on 1995, the protection of trademarks is possible with registry. For this reason, trademarks registered at the trademark registry established under the Turkish Patent Institute (TPI) give their owner the right of monopoly and are protected within the borders of the country. However, if a trademark is not registered according to Decree No 556 in Turkey, it does not mean that that trademark will not be protected within the borders of the country. Basically, as to Turkish Law, there is not an obligation to use a trademark, it is not mandatory for every trademark used to be registered at any official institution. The nonexistence of registration obligation in our law has made it a must for the non-registered trademarks to be protected. As to Decree No. 556 even though the protection of trademarks is based on registry, a non-registered trademark is also protected according to the provisions of the mentioned decree within the bounds of the country as well. In this study, the regulations related to the subject of the Decree No. 556 permitting the protection of a non-registered trademark within the borders of Turkey will be considered. What is meant by the concept of non-registered trademark is a trademark not registered at the TPI in accordance to Decree No. 556. The basic principles governing the 
protection of the trademark will be considered in the study, along with the conditions in which a trademark non-registered at TPI will benefit from the regulations of the Decree No. 556.

\section{Basic principles for the protection of trademarks}

- Registry principle; as to the registry system, the means of having a right on the trademark is based on it being registered. The system accepted by the Decree No. 556 is this system because the trademark protection conferred by this Decree is acquired by registration. In this system, in terms of the creation of the right, the trademark registration is of an establishing nature and not explanatory (Ayhan, 2008). As a result of this, the person registering the trademark first has the right of monopoly on that trademark. The right of monopoly gives owner of trademark the right to prevent third parties to use their trademark without permission.

- Territoriality principle; the system which is the basis of intellectual property rights protection is the territoriality principle. According to this principle, the registration confers protection only in that country in which the registry of the trademark is made. That is a trademark is accepted as a non-registered trademark outside the borders of the country in which it is registered.

- Limited protection principle; the protection conferred by the trademark registrations is limited with the trademark to be registered and the goods and services in which the trademark shall be used. As a result of this principle, a trademark is protected in the class of goods and services it is registered and classes of the like. With the objective to confer for the ease and harmony in the registry of trademarks, "Nice Agreement Concerning the International Classification of Goods and Services for the Purposes of the Registration of Marks" agreement has been organized. This agreement has been effective in Turkey, as of 1.1.1996. Trademarks in which protection is not limited to class are well known trademarks. Well known trademarks confer protection in all classes regardless of being registered or not.

- Preemptive right principle; what is meant by preemptive right is that if the trademark registry application is based on an application made in one of the countries that is a member of the Paris Convention, it is the preemptive right arising from the first application. This right must be used within six months of the date of the first application. As to the territoriality principle, the trademark owner must register her/his trademark in every country separately. If the trademark owner has made a trademark application in a country which is a member of the Paris Convention, in the applications made in any one of the other countries being part of the Convention within 6 months of the date of the application, the application date is accepted as the first application date. In other words, trademark of trademark owner, in the country which is a part of the Convention, is taken under protection starting from the date of the first application. Its trademark is under protection in other countries that are parties to the Convention within six months after this date. 


\section{The concept of non-registered trademark}

In its most general definition, a trademark is named as all kinds of introductory signs providing its goods and services of an enterprise to be distinguished from the goods and services of another enterprise. As all meaningful or meaningless signs consisting of elements like names of persons, words, shapes, numbers, emblems, pictures, letters, colors etc, can be used as trademark, sings that can be visualized by drawing and that can be published and reproduced by printing can also be used as a trademark (Decree a. 5). The most important characteristic of trademarks is that they have a distinctive nature. This characteristic is the characteristic that confers the trademark to become a trademark required for the presence of trademark to be formed (Tekinalp, 2003) ${ }^{1}$. Provided that it has the distinctive condition; it is possible for all kinds of signs to be registered as trademark (Çolak, 2014).The distinctive characteristic of the trademark refers to characteristics and elements of any sign providing it to be different from the others. As a sign can be distinctive at the beginning, it can achieve this characteristic later on (Özdilek, 2007). With the Decree No. 556 the ownership of right on the trademark is obtained with registration (Decree No. 556 a. 6). As to this regulation, the owner of a non-registered trademark cannot benefit from the protection provided by the Decree. Even though the basic principle is the registry system, it will not be false to say that, the trademark is protected under the coverage of the Decree under certain extraordinary cases which are the subject of this study. However if the trademark owner wants to take advantage of the special regulations provided by the Decree No. 556, in that case the registry of the trademark is mandatory. The registry is made at the TPI. What is meant by the concept of non-registered trademark which is the subject of this study, are those domestic or foreign trademarks which are not registered in Turkey according to the Decree No. 556. The domestic or foreign non-registered trademarks of the goods and services that are not in the classification of the trademarks of those goods and services that are registered are also included in this concept.

\section{Methods of protection for non-registered trademarks in Turkey}

Even though the protection of trademarks is based on registry as to the provisions of Decree No556, trademark right can also be obtained by usage as to the mentioned regulation. It is also possible for a domestic or foreign trademark obtained by usage to be protected in Turkey as well. Then the trademark owner does not register her/his trademark but she/he has made it well known in the market by using it. In this case, the real owner of the right on the trademark is the first person to use the trademark ${ }^{2}$. The fundamental basis of this protection is the unfair

1 The fact that a sign to be registered bears the distinctive condition shall eliminate the absolute registration barriers and some nullity reasons along with it.

2 The priority right of obtaining the right on a trademark belongs to the person bringing the trademark to the known position where this is called the real right owner, and in this case the right on trademark is born before registration. Registration in here has an explanatory rather than establishing effect. In contrast, the registration of a trademark before using that trademark has an establishing effect. In this case the registration confers the owner a conditional right at the beginning only. The thing is that such an act is regarded as violation of the real trademark right of the real right owner against the person obtaining the right by registration of the same and non-distinctively similar trademark how so ever registering as a trademark. The real right owner can prevent this action by the provisions of the Decree No 556 as well. 
competition provisions of the Turkish Commercial Code (TCC). Unfair competition provisions are the general provisions in the TCC No 6102 a. 54 etc. Actually, whether a trademark is registered or not, it is protected as to unfair competition provisions in all conditions. But nonregistered trademarks cannot take advantage of the provisions of Decree No. 556 as a rule. The protection of non-registered trademarks as to unfair competition provisions is not the subject of this study. The subject of this study is the protection of non-registered trademarks under the light of exceptional regulations in Decree No 556. Actually, trademarks not registered at TPI in Turkey can be protected within the borders of the country as to Decree No 556. However, the coverage of such a protection varies according to the type of the non-registered signs (Tekinalp, 1997.). The exceptional conditions of the protection of non-registered trademarks in Decree No 556 will be considered in the next section of the study.

\section{Protection of a non-registered trademark as to the regulations of Decree No. 556}

Although Decree No. 556 has accepted the registry basis, the same Decree has moved away from the principle of registry at some points. In other words, it has granted superiority to the registered trademark over the non-registered trademark. These conditions providing superiority to the registered trademark are these:

- Well-known trademarks in the scope of Paris Convention (Decree No 556 a. 7 (1) i),

- Well-known trademarks in terms of different goods or services (Decree No 556 a. 8 (4)),

- Trademarks benefiting from pre-emptive rights (Decree No 556 a.25-28),

- Signs used in trading (Decree No. 556 a.8 f.3 pp. a and b),

- Signs obtaining a distinctive nature (Decree No 5567 (2)),

- Trademarks against unauthorized filing by agents (Decree No 556 a. 8 (2)),

- Trademarks vested in third parties (Decree No 556 a. 8(5)).

As it can be understood from these conditions, Decree No 556 has given place to the usage of non-registered system at an important ratio (Yasaman, 2004, p. 155 etc.). However, it must be mentioned that the non-registered trademark owner cannot take advantage of all the protective clauses of the Decree No. 556. The owner of the non-registered trademark can benefit totally from the clauses of the Decree No. 556, after registering her/his trademark by only using the possibility of filing a nullity action and cancellation of registration granted to her/him (Tekinalp, 1997).

\section{I. Protection of well-known trademarks as to the Paris Convention (Decree No. 556 a.7 (I) i)}

The trademark protection present at a. 7, paragraph 1, clause (1) of the Decree No.556 is among the exemptions of the registry system.

According to Article 7(1)(i), trademarks that have not been authorized by their owners and well known marks within the meaning of Article 6 of the Paris Convention shall not be registered. 
According to this, a trademark duly registered and known in any one of the countries being parties to the Paris Convention is accepted to be under protection is protected in the other countries that are parties as well. In other words, the countries that are members to the Convention have accepted to prevent the registration of well-known trademarks in the name of others. But in order for a trademark non-registered in Turkey to benefit from this protection, it is a must that it is a trademark recognized under the Paris Convention primarily, and that this trademark must be recognized in Turkey as well. In this case, the well-known trademark owner can object to the registry of its trademark by third parties for the same goods and services in Turkey because of the well-known nature of its trademark. If the third party registry has become aware of registration, in that case a nullity case can be filed. Protection of the same, same type, similar or related goods and services are provided under the coverage of a. 7/1 (i) of the Decree No. 556 basically.

As a result, Decree No. 556 provides the owner of a trademark not registered in Turkey but well known in the countries which are one of the parties of the Paris Convention, both the registration in the registry of the trademarks of other the goods and services in the same or similar classifications and the prevention of the use of the trademark by others the protection coverage of a. 7 (1) is the non-registered foreign trademarks in Turkey.

\subsection{The protection of well-known trademarks in terms of different goods or services (Decree No 556 a. 8 (4))}

As to the limited protection principle where trademarks are protected in the registered goods and services classifications, they are not protected in the non-registered goods and services classifications. For this reason the use of same trademark or a similar trademark that is registered or that is applied for registration in a different classification of goods and services does not create an irregularity according to Decree No. 556. However if the trademark that is registered or that has been applied for registration is a well-known trademark, then upon the opposition of the trademark owner, even though it shall be used in different goods and services, the registration application of the latter trademark will be refused or that trademark will be annulled if it has been registered. The objective of this regulation is to prevent of taking unfair advantage of the reputation and distinctive power of the well-known trademark as well as the prevention of the detriments that could be made to the reputation and the distinctive character of the trademark (Decree No 556 a. 8 (4)). As to the mentioned clause, the trademark under the coverage of protection must be a trademark registered and well known in Turkey. But the existence of these two conditions alone is not enough. Even though a trademark is so well known, if one of the conditions listed on a. 8 (4) is not present, then that trademark will not be protected in the different goods and services classifications it is not registered. Consequently, in order for a well-known trademark to be protected in goods and services classifications in which it is not registered at, at least one of the conditions mentioned in the provision must exist. These conditions are; the possibility of the unfair benefit of the trademark which is the same and similar to the well-known trademark, from the well-known situation of the level of the well-known situation of the well-known trademark in 
the society, the condition of the reputation of the well-known trademark to be damaged, or the condition of the creation of results that may result in the damaging of the distinctive characteristics of the well-known trademark (Dirikkan, 2003). Under the coverage of this provision, the rejection of the latter registry application even for different goods and services with the existence of the mentioned conditions creates the result of the provision of this protection for the same or similar goods and services as well.

The protection of well-known trademarks provided under the coverage of the Paris Convention is different from the protection of well-known trademarks provided in here. Before everything else, where the trademark protected under the coverage of a. 7 (1) is the trademark which is the foreign trademark used in the member countries of the Paris Convention but not registered or not used in Turkey, the trademark protected under the coverage of a.8 (4) is the domestic or foreign trademark registered and well known in Turkey. Where the basis of the protection under the coverage of a. 8 (4) is oriented for the class of different goods and services of the well-known trademark not registered in Turkey, the well-known trademarks under the coverage of a. 7 (1) i are towards the trademarks of the same or similar goods and services (Dirikkan, 2003).

\subsection{Protection of trademarks as to pre-emptive rights principle (Decree No 556 a. 25-28)}

As we have stated at the subtitle 2 of this study, as a requisite of the territoriality principle in the registry of the trademark, the trademark is protected only in the country it is registered. Therefore, the trademark owner to supply the good or service in many countries must register her/his trademark in those countries and must perform the required application for this. As a rule, the protection of a registered trademark starts from the moment the registration application is made. The exception to this rule is the pre-emptive right in trademarks. Pre-emptive right is a right with priority owned in the subject of registering a trademark (Bozgeyik, 2007).

Two kinds of preemptive rights have been articulated in Decree No 556. The first one of these is the application priority arising from the registry application made in a foreign country, the second one is the one arising from the display in exhibitions. What is meant by application priority is that if a person citizen of one of the countries which is a member of the Paris Convention or even if not a citizen ,residing in one of these countries or is a real or judicial person who has a commercial establishment operating in one of these countries, has duly applied to the authorities in one of the countries which is a member of the Paris Convention, for the registry of the trademark; and if applies for the registry of the same trademark in Turkey within six months from the time of this application date, the initial application date is accepted as the application date (Decree a. 25). In order for this result to arise, the trademark owner must claim the pre-emptive right in the first application and must realize the application in Turkey within six months from that date. In case a claim is made for pre-emptive right in Turkey because of a trademark application made in a foreign country, the pre-emptive right document received from the authoritative body in the country where the initial application was made and the Turkish translation of this document 
must be presented to the TPI during the registry application. The pre-emptive right acquired in this way is related only to the goods and services for which the registry is requested for its owner. For different goods and services other than this, there is no pre-emptive right (Çolak, 2014).

What is meant by exhibit priority is that those exhibiting the goods or services that will be used in the registry application of the trademark at national or international exhibitions or at exhibitions accepted as official or non-official in countries that are members of the Paris Convention, can benefit from the pre-emptive right in case they make an application for trademark registration in Turkey within six months from the date of the exhibit at the exhibition. The beginning of six months period is the date of exhibition. However, if the goods and services have been displayed before the official opening day of the exhibition in a visible manner, the period of the priority right starts from the date the goods are placed in the exhibition stand or the service is displayed. Those real or judicial persons having a residence or those having an industrial or commercial activity within the borders of The Republic of Turkey can take advantage of this right. Moreover, persons having the right to apply within the provisions of the establishment agreements of the Paris Convention or the World Trade Organization (TRIPS) can also benefit. The trademark owner must request the pre-emptive right in this area during the initial application. If there are more than one priority right applications of goods and services displayed in an exhibition, the first displayer, if the exhibition has occurred at the same date; the one making the application first is the right owner (Decree a. 26). As in the application priority, the pre-emptive right in the exhibition priority is present in terms of the goods and services exhibited and then applied for registration (Çolak, 2014).

\subsection{Protection of the non-registered trademarks or signs (Decree No 556 a. 8 (3) a-b)}

The protection of non-registered trademarks or sign is articulated clearly in a. 8(3) regulating the relative rejection reasons:

"Upon opposition by the owner of a non-registered trademark or of another sign used in the course of trade, the trademark applied for shall not be registered provided that:

a) the rights to the sign were acquired prior to the date of application for registration of the trademark, or the date of priority claimed for the application for registration;

b) the sign in question confers on its owner the right to prohibit the use of a later mark"

As to this provision the existence of two conditions is necessary for the protection of nonregistered trademarks. The first one of these is the case where a right has been acquired before the date of the application of a non-registered trademark or sign by a third party to take advantage of the provision or before the priority date specified on the date of the application. Hence, if only a previous usage is the case, the person owning this right can oppose to the registration of the sign. The second one is the fact that it confers on its owner the right to prohibit the use of a later mark. The owner of a trademark not registered according to Decree No 556 a. 8 (3) can prohibit 
the registry of the trademark by others later on at the existence of the requisites of the provision. As it is listed among the relative rejection reasons TPI cannot decide ex officio rejection of the registry request with the reason that the trademark requested to be registered is same or similar as to have a likelihood of a trademark used without registration. The one that might prevent from registration in here is the real owner. The real owner can prevent the registration and he can also file a nullification case as well. It must be stated that the nullity decision must be made only for those goods and services classification and for those similar to it, on which the real owner has used the trademark (Çolak, 2014). As the trademarks not registered in Turkey can take advantage of this arrangement, those trademarks registered in a foreign country but not registered in Turkey, however are used in that country and has acquired familiarity as a result of this usage (Uzunall, y. 2012).

The provision aims to protect the real owner using the trademark or the sign first and introducing it commercial life. What is meant by the non-registered trademark in the provision is the signs not registered as to Decree No 556 but are used specifically as the trademark. What is meant by the term another sign used during trade is the distinctive signs used in commercial life apart from the trademark, like the commercial title, business name etc. (TPI, 2011)

\subsection{Protection of signs acquiring distinctive quality as a result of usage (Decree No 556 a. 7 (2))}

As to this provision implemented later on with Law No 4128,

"the provisions of subparagraphs (b), (c) and (d), may not be invoked to refuse the registration of a trademark that has been used before registration and through such use has acquired distinctive character in relation to the goods and services for which it is to be registered."

With this provision present among the absolute rejection reasons of the trademark registration, even if a trademark does not have a distinctive power initially, if it has been used before the registry date and has acquired a distinctive quality related to the goods and services for which it is to be registered, the registry cannot be refused by the TPI (Yllmaz, 2008). However, the trademark owner is required to prove the acquisition of distinctiveness of the trademark intended to be registered, by usage. Acquiring distinctiveness by usage can be possible in only 3 conditions. These conditions are as follows.

- trademarks lacking distinctive character (7 (1) a),

- being descriptive (7 (1) c),

- being customary in trade /usable by everyone in commercial field (7 (1) d).

The case of distinctiveness as a result of usage is in the character of exemption of absolute rejection conditions articulated in the coverage of Decree No 556 a. 7 (1) a, c and d. These conditions are 
limited in number. In cases other than these wherein signs cannot be registered as trademark as a result of absolute registry restraints, they cannot acquire distinctive characteristic as a result of usage (TPI, 2011). Moreover this case can be included among the exemptions of this provision with the assumption that a trademark which has been registered or that is applied for registry can acquire distinctive power by usage before registry from the trademarks which are the same or so similar trademarks as not to be distinctive. This extraordinary condition cannot be taken into account ex officio by the TPI. For this reason, this case must have been stated clearly during the application or in case of the phase of opposition for the rejection of the application (Karahan, 2002).

\subsection{Protection of non-registered trademarks against unauthorized filing by agents (Decree No 556 a. 8 (2))}

This arrangement, present at a.8 second paragraph setting out the relative representation reasons, protects the trademark owner against unauthorized filing by agents. As to the provision in question, in case of the unauthorized filing by agents with the intention of registering the trademark in its name without the consent of the trademark owner, the trade owner has the right to prevent the registration of the trademark by opposition. Concepts of agent, commercial proxy or representative in the provision should not be interpreted in the narrow sense. Commercial proxy/ representative can at the same time be the exclusive seller, distributor, agent etc. of the trademark owner in Turkey (Çolak, 2014).

In order for the trademark owner to use the opposition right arising from this provision, it is mandatory to have a prior trademark right acquired but which has not been registered at the TPI. Along with this, a relation in the nature of a proxy or representation characteristic must exist between the trademark owner and the person wishing to register the trademark in her/his name. The person opposing her/his commercial proxy/representative must prove that she/he is the legal owner of the trademark on the date of the opposition. That is, the opposing person must present evidence relating to the fact that herself /himself is the real owner of the trademark (Karahan, 2002,). It is mandatory for a commercial proxy/representative filing for registration without the permission of the trademark owner not to be able to present a valid justification. In case there is a valid justification, the opposition of the trademark owner is refused. Even if conditions like the commercial Proxy or the representative to perform important activities for the foreign trademark to be introduced in Turkey and the trademark owner not renewing the trademark in Turkey etc. can be mentioned as examples for valid justifications, the determination of what the valid reason is in every solid case must be determined as to the conditions of the agreement between the parties (Çolak, 2014). It must be mentioned that as a requisite of the limited protection principle in trademarks, the trademark owner can oppose only to the applications including same or similar

goods and services in which there is the probability of the goods and services of the trademark to be confused with those of the trademark. 


\subsection{Protection of the personal rights, copyrights and other industrial property rights vested in third parties (Decree No 556 a. 8(5))}

Decree No 556 Article 8(5) provides for the protection of other non-registered rights, such as rights to a name, photograph, copyright work or any other industrial property rights vested in third parties. Such rights can result in the rejection of a trademark application through opposition.

Geographical signs, commercial title, design register etc. can be mentioned as examples for industrial property rights. The special rights subject to the provision need not be registered in the protected field necessarily. Special right owners mentioned in the registration or nonregistration provision can oppose to the trademark registration application citing these rights. It is adequate for the trademark subject to the opposition to cover one of the rights listed above without requiring any other condition. In case of the rejection of the opposition by the TPI, as the person having one of these rights can file for a cancellation case against the TPI decision, she/he can also file a nullity case if the trademark registry has been made (Karahan, 2002).

\section{Legal and penal sanctions in the protection of non-registered trademarks}

\section{I. Legal sanctions}

Even though the Decree No. 556 based on the registry system for the protection of trademarks is permitting the protection of non-registered trademarks, the protections conferred for such trademarks are limited. As the owner of a trademark registered as to the provisions of Decree No 556 can benefit from all protections in a. 9/2, the owner of a non-registered trademark does not have these protection areas. The protection areas conferred for the non-registered trademarks by the Decree No 556 consist only of opposition to the registry, filing an annulation case, filing for a damages case articulated in a. 44/2 in case of the presence of nullity case and its conditions.

It is articulated in Decree No 556 a. 35. In this method, the third party applies to the TPI to register her/his trademark. TPI, which process the application, refuses the application if the conditions are present after performing a preliminary examination, if there is not any rejection reason publishes the trademark together with the registry application at the related bulletin. Non-registered trademark owner who will be experiencing a loss from the registration of the trademark published at the bulletin can object with the reason of the existence of the absolute and relative rejection conditions articulated in articles 7 and 8 of the Decree or with the reason of a trademark application with bad faith. The opposition must be made in writing and with reason within 3 months starting from the publishing of the trademark applications to the TPI. Upon opposition, TPI makes a positive or negative decision. It is also possible to object to the decision made by the TPI. The owner of the non-registered trademark not obtaining a positive result from the opposition procedure can file a nullity case at the court.

Nullity case is articulated at Decree No 556 a. 42 and others and the grounds for this case are limited. The nullity case at the mentioned provision is for the trademarks registered at the TPI 
in Turkey. Therefore, nullity cases can be filed only for trademarks registered at the TPI (Çolak, 2014). That is, the subject of a nullity case is the annulation of the registration entry of a registered trademark registered by TPI after it has been understood that the registry conditions have not been fulfilled (Karahan, 2002.). For this reason, the annulation of a non-registered trademark is not possible. But the basis of this study is the protection of non-registered trademarks under the coverage of Decree No 556. We had mentioned that non-registered trademarks are protected under the coverage of Decree No. 556 at the presence of some conditions as a requisite of our study. According to this, if a trademark that must not be registered is registered by the TPI, then in that case the owner of the non-registered trademark can sue for this registry to be annulled at the presence of rightful reasons. For example, if the trademark subject to nullity is a well-known trademark as to Decree No 556 a. 7 (1) then in that case even if that trademark is not registered at the TPI, it cannot be registered for the same or similar goods and services by others. In this case, the non-registered trademark owner can file a nullity case within5 years starting from the date of registration against the person registering the trademark in her/his name basing it upon the absolute rejection reason (Dirikkan, 2003, p. 259). If there is bad faith in the registration of the trademark, in that case it has been stated by both doctrine and in the Court of Cassations decisions that the 5 year period shall not be applied (Karahan, 2002, p. 80; Court of Cassations Assembly of Civil Chambers Outset 2011/11-529, Decision 2011/643, Date 19/10.2011). As to limited protection principle which is the basis of trademark law, the nullity of trademark is related to the part of registered goods and services. The court decides on this case for nullity related only for the registered goods and services subject to nullity. In case court rules for the nullity of the trademark, the ruling is retroactive except for some situations. The final decision of a court related to the nullity of a trademark, incurs a provision for everyone (Decree a. 44). It is a must for the nullity decision to be ruled by the court. The results of a decision ruled at the nullity case are retroactive without prejudice to the exceptions. Compensation for damages claim can also be asserted related to the compensation of the loss incurred from bad faith activity of the trademark owner (Decree a. 42/2).

Other than this, in case of the presence of the conditions at Decree No 556 a. 8/4 setting out the protection of the well-known trademark registered in Turkey in other non-registered classifications, the trademark owner can claim the prevention and elimination of the violation, the compensation of the losses, the impoundment, the destruction, the notification of the court decision to the related and announcement to public by publishing of the goods which require penalty of violation of rights because of production or usage as well as the vehicles and the means etc. required for those goods. Moreover, as the trademark owner can claim for the impoundment of the goods at the customs, she/he can also claim the detection of evidences and precautionary measures (KHK a. 9-61 etc.). It must be stated that if the non-registered trademark is a wellknown trademark within the meaning of Decree No 556 a. 7 (1), the trademark owner even though cannot benefit directly from the rights conferred by the mentioned clauses against monopoly and violation against the trademark, as to Decree a. 4, can prevent her/his trademark to be used in Turkey (Dirikkan, 2003.) 


\subsection{Penal sanctions}

As well as the legal sanctions of the violation related to trademark, there are also penalty sanctions as well. Penal sanction at Decree No 556 a. 61/A has been amended by Law No5833 effective on the date 28.01.2009. Law No 5833 has articulated the pre-condition of registration, differing from the old regulations ${ }^{3}$. In crimes requiring preconditions, it is not possible for the crime to be committed without the occurrence of the precondition (Soyaslan, 2005). Therefore, a person not registering the trademark cannot benefit from the penal protection proposed in Decree 556 as a rule. That is, even if a trademark is not registered in Turkey at the TPI, it has legal protection whereas it does not have penalty protection. In this case, the person not registering the trademark can benefit from the penalty protection as to general provisions. Nevertheless, there is not a regulation preventing the trademark owners not registering the trademark from benefiting from the general provisions. The mentioned general provisions are the tort provisions in The Code of Obligations 49 and the following articles and the unfair competition provisions in a. 57 and the following, as well as the unfair competition provisions in the TCC a. 54 and the following. However, the trademark owner can benefit against the violator against the registered trademark only from the provisions in the TCC because the Code of Obligations does not include any penal sanctions. In this case, the trademark owner can only benefit from the penal protection in the TCC regulation related to unfair competition. According to TCC No 6102 a. 62 (1) a, those committing one of the conditions of unfair competition stated in a. 55 deliberately are sentenced with imprisonment up to two years or criminal fines. Unless the activity subject of unfair competition does not require a heavier punishment.

\section{Evaluation and Conclusion}

Even though the protection in Turkey based on Decree No 556 is based on registry, in some cases a non-registered trademark can also benefit from the protection in the aforementioned legal regulations. As can be noted from the exemptions of registry principle that is the subject of our study, there are provisions contrary to the registry principle in the Decree. These provisions almost have the character of weakening the registry principle on which the Decree is based on. In Turkey, it is possible for both the domestic and the foreign non-registered trademarks to be protected upon the presence of the conditions we have considered in our study. However, the protection coverage of non-registered trademarks is narrower as to registered trademarks. The protection areas conferred for the non-registered trademarks of the Decree No 556 consist only of opposition to registry, claim of nullity of a registered trademark, and filing compensation case set out in a. 44/2, in case of the existence of the conditions. However if the trademark owner wants to take advantage of the special protective provisions of Decree No 556, in that case the registry of the trademark is mandatory. While the non-registered trademarks

3 Preconditions are those elements that must be present before the criminal elements. Stated otherwise, precondition is the precondition of the activity creating the crime. Hence, it is not possible for a crime to be committed without preconditions. 
have legal protection even if they are limited, as to Decree No 556, they do not have penal protection. According to this, in order for the penal sanctions in Decree No 556 to be applied, the condition of the trademark to be registered in Turkey has been set. For this reason, the person not registering the trademark shall benefit from the general provisions instead of the Decree No 556 in the case of penalty sanctions.

\section{References}

Ayhan, Rıza. (2007). Ticari işletme hukuku, Ankara: Yetkin.

Bozgeyik, Hayri (2007). Markalarda Rüçhan Hakları, Fikri Mülkiyet ve Rekabet Hukuku Dergisi, 7, 51.

Çolak, Uğur (2014). Türk marka hukuku, İstanbul: On İki Levha.

Karahan, Sami (2002). Marka hukukunda hükümsüzlük davaları, Konya: Mimoza.

Özdilek Yurdaer (2007). Markanın kullanımla ayırt edicilik kazanması 11. hukuk dairesinin konuya ilişkin iki yeni kararının değerlendirilmesi, prof. dr. Hüseyin Ülgen’e armağan, İstanbul: Vedat.

Soyaslan, Doğan (2005).Ceza hukuku genel hükümler, İstanbul: Yetkin Yayınları

Tekinalp, Ünal (1997). Yeni marka hukukunda tescil ilkesi ve tescilsiz işaretlerin hukuki durumu, Kenan Tunçomağ’a armağan, Ankara: Beta.

Tekinalp, Ünal, (2003). Ayırt edici nitelik kazanma, Prof. Dr. Fahiman Tekil’in anısına armağan, İstanbul: Marmara Üniversitesi Hukuk Fakültesi.

Türk Patent Enstitüsü, (2011). Marka inceleme kılavuzu.

Uzunall, Sevilay (2012). Markanın korunmasının kapsamı ve tazminat talebi. Ankara: Adalet.

Yasaman, Hamdi.(2004).Marka hakkının niteliği ve tanınmış markalar hakkında Yargıtay 11. hukuk dairesinin kararı üzerine düşünceler. Galatasaray Üniversitesi Hukuk Fakültesi Dergisi, 2, 155. 